\title{
Is the Martinique ground snake Erythrolamprus cursor extinct?
}

Stephane Caut and Michael J. Jowers

\begin{abstract}
The Caribbean Islands are a biodiversity hotspot where anthropogenic disturbances have had a significant impact, causing population declines and extinction of endemic species. The ground snake Erythrolamprus cursor is a dipsadid endemic to Martinique; it is categorized as Critically Endangered on the IUCN Red List and is known only from museum specimens. The snake was common on Martinique during the 18th and 19th centuries but there have been no reliable sightings since 1968, suggesting it may have gone extinct, probably as a result of the introduction of the small Indian mongoose Herpestes javanicus auropunctatus. However, the islet known as Diamond Rock, south-west of Martinique, is mongoose-free and the last reported sighting of E. cursor there was in 1968 . The islet was last occupied during the Napoleonic Empire (the early 19th century), is now completely protected, and is difficult to access (it spans 5.8 ha, with a maximum elevation of $175 \mathrm{~m}$ ). We conducted the first extensive survey of the islet, over 10 days, to clarifty the status of E. cursor. Our study revealed that unique conditions exist on Diamond Rock (i.e. aridity and a distinct potential prey community) and that E. cursor would have had to modify its ecology to persist on the islet. Although the rugged terrain of Diamond Rock makes it difficult to explore, it is probable that $E$. cursor is now extinct.
\end{abstract}

Keywords Alien species, conservation, Diamond Rock, Erythrolamprus cursor, extinction, Liophis cursor, Martinique, West Indies

The Caribbean Islands are considered to be a biodiversity 1 hotspot because they harbour a high concentration of endemic species that are threatened by habitat loss and invasive species (Myers et al., 2000). Of the region's herpetofauna, $99 \%$ of frogs and $93 \%$ of reptiles are endemic (Hedges, 2001). The Critically Endangered endemic dipsadid snake Erythrolamprus cursor (previously known as Liophis cursor, Lacépède, 1789, Plate 1) was common

Stephane Caut (Corresponding author) Consejo Superior de Investigaciones Científicas, Departamento de Etología y Conservación de la Biodiversidad, Estación Biológica de Doñana, C/Americo Vespucio, s/n (Isla de la Cartuja), Sevilla E-41092, Spain, and ANIMAVEG Conservation, 58 Avenue Allende, Villejuif F-94800, France. E-mail stephanecaut@gmail.com

Michael J. Jowers Centro de Investigação em Biodiversidade e Recursos Genéticos, Universidade do Porto, Vairão, Portugal

Received 18 December 2014. Revision requested 13 January 2015

Accepted 6 February 2015. First published online 22 June 2015. throughout Martinique during the 18th and 19th centuries (Moreau de Jonnès, 1818). It was last observed on the Martinique mainland in 1965, when a single individual was caught near Fort-de-France. There are two potential reasons for its decline: people may have mistaken it for the venomous lancehead Bothrops lanceolatus, which may have led to its eradication, and the small Indian mongoose Herpestes javanicus auropunctatus, an invasive predator, was introduced to the West Indies at the end of the 19th century, resulting in declines and extirpations of reptile species (Henderson, 1992).

To the south-west of Martinique, c. $2 \mathrm{~km}$ from the coast, lies a volcanic islet (spanning 5.8 ha, with a maximum elevation of 175 m; Fig. 1a; Plate 2) known as Diamond Rock. The last published record of E. cursor is associated with this unique ecosystem (the snake was observed there in 1962; Lazell, 1967), and the last specimen was collected on the islet in 1968 (Breuil, 2009). Diamond Rock was occupied by the English during the Napoleonic Wars (1804), when c. 100 men lived there for 17 months, sleeping in caves. Since this period of occupation few records of Diamond Rock have been kept but it seems to have remained uncolonized by the mongoose. The site is now fully protected and people have been banned from landing on the islet since 2008. Fishermen and tourist boats anchor near Diamond Rock, and there have been reports of snakes basking on shoreline rocks. However, several 1-day surveys for the species failed to locate it (Breuil, 2009; M. Dewynter, pers. comm.). The lack of any confirmed sightings of the snake since 1968 suggests that it is probably extinct (Honegger, 1981). The aim of this research was therefore to carry out an extensive survey to elucidate the species' status on Diamond Rock.

Because of the difficulty of exploring the steep slopes of Diamond Rock, and given its protected status, we surveyed the islet during 4-14 June 2014 as a two-person team. We used several methods to search for all potential traces of E. cursor. Firstly, eight snake-specific intercept traps (cylindrical cages $80 \times 15 \mathrm{~cm}$ with cones at the extremities, modified after Linnell et al., 1998) were set in various microhabitats (near rocks, tree trunks, crevasses and at the base of stone walls; Fig. 1b) and were checked twice per day (8o trapnights total; Table 1). Some traps were baited with live mice captured on the islet (8 trap-nights; Table 1). Secondly, we searched for snakes, snake eggs and sloughed skin in all the various habitats on the islet both during the day and 


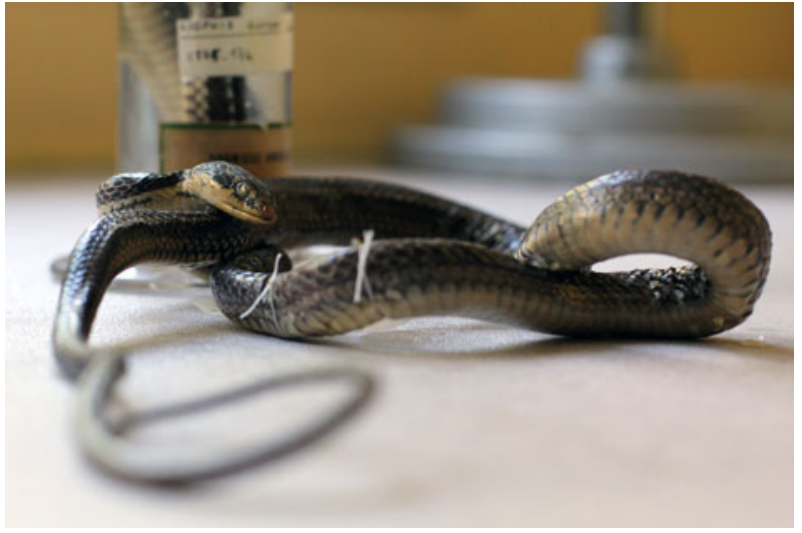

Plate 1 Museum specimen (MNHM 1887.0120) of the dipsadid racer Erythrolamprus cursor, endemic to Martinque. Photograph by Stephane Caut.

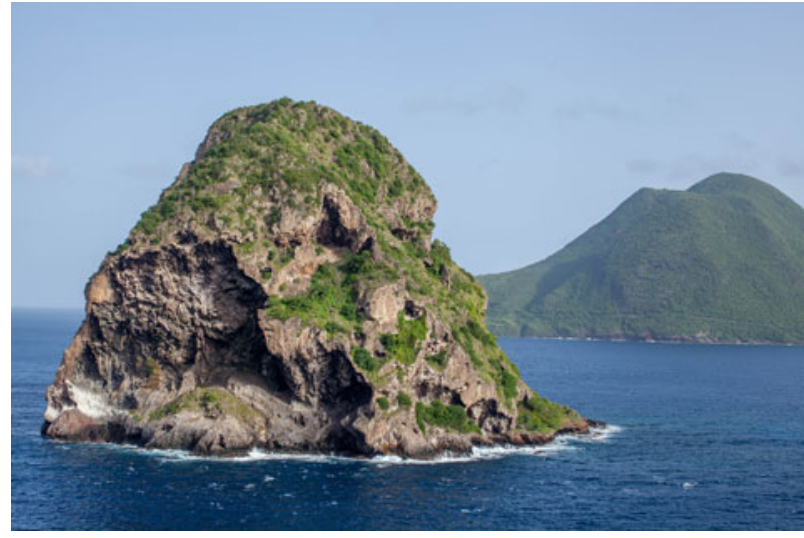

Plate 2 Diamond Rock. Photograph by Stephane Caut.
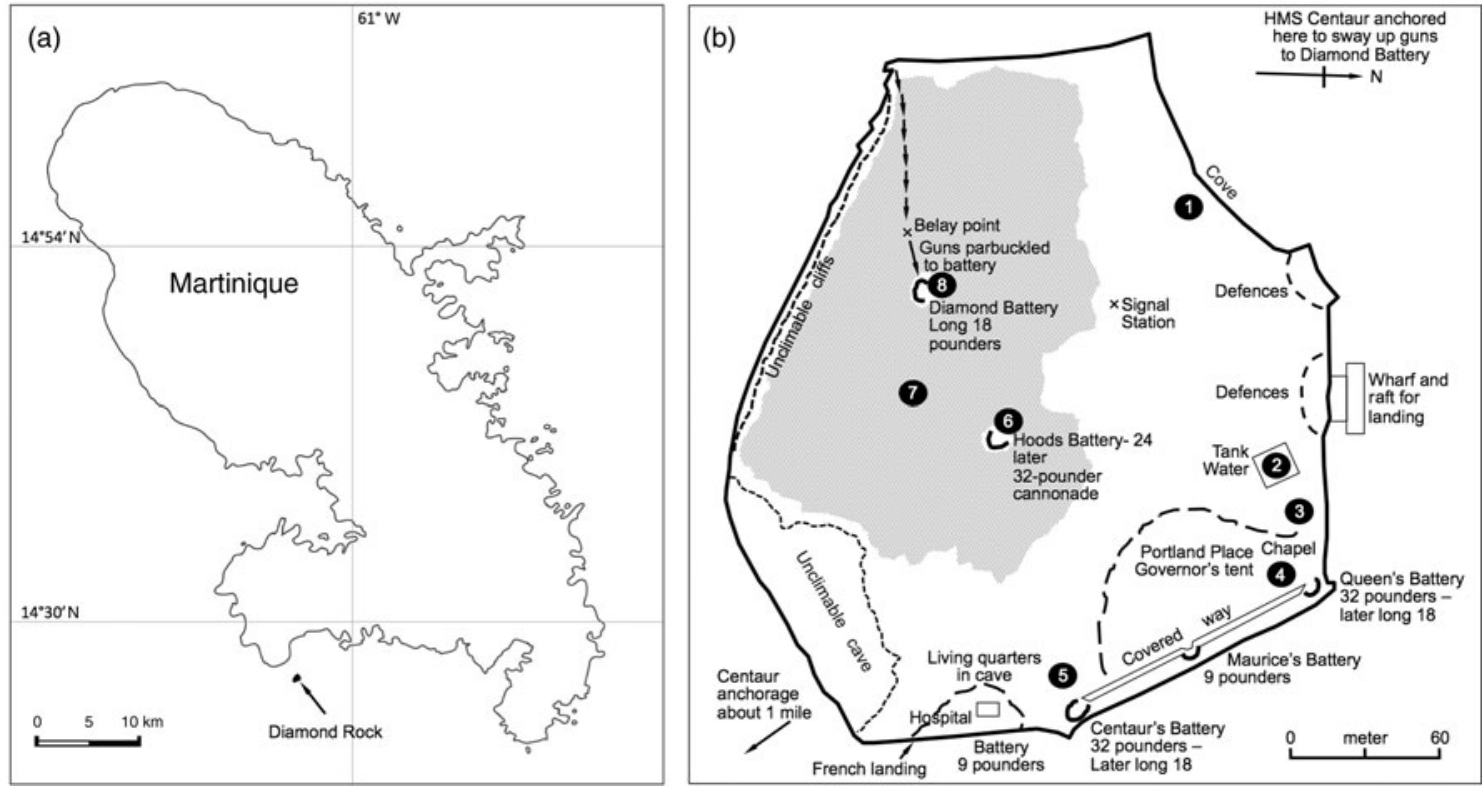

Fig. 1 (a) Location of Diamond Rock off the coast of Martinique; (b) map of Diamond Rock from the period of English settlement (Commodore Hood's dispatch, 14 August 1804; Stuart \& Eggleston, 1978), with the locations of the eight trapping sites (filled black circles).

at night (12 hours per day per researcher). To examine $E$. cursor's potential trophic relationships with other species on Diamond Rock (predator-prey and/or competitive interactions) we compiled an inventory of the species we observed during the survey. To confirm the presence of invasive rodents we used INRA rat traps $(34 \times 13 \times 13 \mathrm{~cm})$ and mouse traps $(12 \times 5 \times 5 \mathrm{~cm})$ baited with peanut butter. Trap lines were established in various habitats (six sites; Fig. 1b), 25 and $5 \mathrm{~m}$ apart for rats and mice, respectively. For logistical reasons we could only use 14 traps (six rat traps and eight mouse traps), which we moved between sites. Trapping was conducted for 1 or 2 consecutive nights on each line transect (a total of 119 trap-nights; Table 1).
We did not detect any signs of the snake. The intercept traps functioned well because we captured all the reptile species that we observed during our visual surveys (Table 1 ). Although some remote areas of the islet remain unexplored for logistical reasons, our survey covered more of Diamond Rock's surface than previous surveys. We ascended steep slopes, whereas previous researchers focused on accessible rocks at low elevations (Lazell, 1967), surveyed for only a few hours, and did not explore the islet extensively. In reports written during the English occupation of Diamond Rock (Stuart \& Eggleston, 1978) snakes were described as abundant near the edge of the water tank (site 2, Fig. 1). The last time E. cursor was observed on Diamond Rock was in July 
TABLE 1 The number of trap-nights with rodent traps (for rat and mice traps, see text for details, combined) and with interception traps for snakes (with number of nights on which traps were baited with live mice), with the species caught in each, at the eight survey sites (see numbered locations on Fig. 1) on Diamond Rock (Fig. 1).

\begin{tabular}{|c|c|c|c|c|}
\hline \multirow[b]{2}{*}{ Site } & \multicolumn{2}{|l|}{ Rodent traps } & \multicolumn{2}{|l|}{ Interception traps } \\
\hline & $\begin{array}{l}\text { No. of trap- } \\
\text { nights }\end{array}$ & Species trapped & $\begin{array}{l}\text { No. of trap-nights } \\
\text { (no. of trap-nights with } \\
\text { live mice bait) }\end{array}$ & Species trapped \\
\hline 1 & 21 & 3 Mus musculus & $6(0)$ & \\
\hline 2 & 21 & 3 M. musculus & $21(3)$ & 9 Sphaerodactylus vincenti; 2 Anolis roquet \\
\hline 3 & 21 & 1 Gecarcinus ruricola & $6(0)$ & \\
\hline 4 & 21 & & $21(3)$ & 2 S. vincenti; 5 Gecarcinus ruricola \\
\hline 5 & & & $6(0)$ & \\
\hline 6 & 21 & 2 M. musculus & $4(2)$ & \\
\hline 7 & & & $8(0)$ & \\
\hline 8 & 14 & 3 M. musculus & $8(0)$ & 2 Gymnophthalmus pleei \\
\hline Total & 119 & 11 M. musculus, 1 G. ruricola & $80(8)$ & 11 S. vincenti; 2 A. roquet; 5 G. ruricola; 2 G. pleei \\
\hline
\end{tabular}

1962 (Lazell, 1967). Weather and temperature conditions during our survey in June (including some precipitation) should have been favourable to observing the snake. Some seabirds (e.g. bridled tern Onychoprion anaethetus, redbilled tropicbird Phaethon aethereus, brown noddy Anous stolidus) breed on Diamond Rock during this season, which could have enhanced the likelihood of spotting the snake if it had adapted to consume eggs or juvenile birds.

Proving the absence of a species is notoriously difficult, and previous work on Erythrolamprus ornatus on Maria Major Island, Saint Lucia, suggests that snakes are difficult to survey, with as few as one located per 30 days of searching (J. Daltry, pers. comm.). Although, it seems likely that E. cursor is extinct, what allowed the species to be abundant on Diamond Rock in the 18th century and persist until the 1950s? Given the aridity on the islet and its distinct prey communities E. cursor would have had to modify its ecology to persist on the islet. Although the genus Erythrolamprus contains 48 species little is known about their ecology and diet, and living E. cursor have never been studied. Studies of the species' trophic ecology (Henderson \& Bourgeois, 1993; Henderson, 2004) were based on the stomach contents of preserved specimens, indicating consumption of frogs (Eleutherodactylus spp.) and lizards (Anolis spp.) and a small proportion of insects. The closest living related species, Erythrolamprus juliae (Jowers et al., 2013), has a similar diet, comprising mainly anurans (Schwartz \& Henderson, 1991; Breuil, 2002). There have not been any reports of frogs on Diamond Rock and we found no evidence of them, and therefore E. cursor probably underwent a dietary shift to prey on the species available (e.g. four reptile species; Table 1). We found that the Martinique anole Anolis roquet was common, especially at lower elevations. Other potential prey present at high densities included seabird chicks, juvenile Antillean fruit-eating bats Brachyphylla cavernarum, and invasive house mice Mus musculus.
Another cause of the snake's disappearance could be the introduction of non-native predators. Diamond Rock was granted full protection only in 2008. During our survey we found no evidence of the presence of superpredators on the islet (e.g. mongoose or feral domestic cat). We did not capture any rats Rattus spp., and based on our experience trapping rodents on other oceanic islands we are confident there are no rats on Diamond Rock and probably never have been. However, mice appear to be present at high densities. They can have devastating, irreversible and ecosystem-changing effects on islands and are known to consume invertebrates, seabird eggs and juvenile seabirds (Angel et al., 2009). On Diamond Rock mice could have affected the snake population directly by consuming juvenile snakes or snake eggs, or indirectly by decreasing prey availability. Egg clutches of E. cursor may have contained no more than five eggs (Arlington \& Henderson, 2004). However, as the mouse population dates from the time of the English occupation in 1804, why was the snake still present on the islet $<50$ years ago?

Lack of data on the species' abundance in the 1950 s is a significant limitation to evaluating the cause of the species' extinction. There may never have been a large population of E. cursor on Diamond Rock, or the population may have decreased during the English occupation. If $E$. cursor on Diamond Rock lived at the same density as $E$. ornatus on Maria Major (1.7-8.3 individuals per ha; J. Daltry, pers. comm.), this would imply $<50$ individuals in total. Such a low-density population would probably suffer from inbreeding depression (e.g. reduced fertility, congenital defects, reduced resistance to disease) and be vulnerable to stochastic forces such as a skewed sex ratio, natural disasters and chance fluctuations in reproduction and mortality (Traill et al., 2007). Alternatively, the disappearance of E. cursor may have resulted from a particular event (e.g. climatic change, species invasion) 
that took place between the 1950 s and 2008, when the islet became fully protected.

Although the complexity of the Diamond Rock ecosystem makes it difficult to explore, we conclude that E. cursor may now be extinct, given that 10 days of extensive surveying and trapping yielded no signs of its presence. It is more difficult to declare a species extinct than to describe or rediscover species. Erythrolamprus cursor is just one example of several reptile species known to survive only on one small island, at a low density (e.g. E. ornatus, Alsophis antiguae, Cnemidophorus vanzoi, Ameiva polops). There is an urgent need to assess these species and to ensure that their habitats are free from invasive species and other potential threats. The invasion of oceanic islands by non-native predators can lead to dramatic effects on island ecosystems and cause numerous extinctions. From a conservation perspective, the Caribbean, a biodiversity hotspot with a large number of species at risk of extinction, is one of the most important areas in the Western Hemisphere.

\section{Acknowledgements}

We thank L. Juhel, I. Ineich and M. Breuil for their help in organizing the survey, and A. Bérubé-Lampron for the documentary films. We also thank Jessica Pearce-Duvet for her English editing services. Appropriate ethical procedures were employed during this research. $\mathrm{SC}$ was granted approval to engage in animal experimentation (R-45GRETA-F1-04) by the French Minister of Agriculture. DEAL Martinique (J. Mailles, N. Boulard and C. Barnérias), the Conservatoire $\mathrm{du}$ Littoral, and ONCFS provided legal support (DEAL-20130510) and allowed us access to Diamond Rock and its facilities. This work was funded by the Consejo Superior de Investigaciones Científicas (JAE postdoctoral contract to SC) and the NGO Animal Conservation.

\section{References}

Angel, A., Wanless, R.M. \& Cooper, J. (2009) Review of impacts of the introduced house mouse on islands in the Southern Ocean: are mice equivalent to rats? Biological Invasions, 11, 1743-1754.

Arlington, J. \& Henderson, R.W. (2004) Communal nesting site in the snake Liophis juliae in Dominica, West Indies. Caribbean Journal of Science, 40, 263-265.

Breuil, M. (2002) Histoire naturelle des amphibiens et reptiles terrestres de l'archipel Guadeloupéen: Guadeloupe, Saint-Martin, Saint-Barthélemy. Patrimoines Naturels No. 54. Institut d'Ecologie et de Gestion de la Biodiversite, Paris, France.

Breuil, M. (2009) The terrestrial herpetofauna of Martinique: past, present, future. Applied Herpetology, 6, 123-149.
Hedges, S.B. (2001) Biogeography of the West Indies: an overwiew. In Biogeography of the West Indies, Patterns and Perspectives (eds C. A. Woods \& F.E. Sergile), pp. 15-33. CRC Press, Boca Raton, USA. Henderson, R.W. (1992) Consequences of predator introductions and habitat destruction on amphibians and reptiles in the post-Columbus West Indies. Caribbean Journal of Science, 28, 1-10.

Henderson, R.W. (2004) Lesser Antillean snake faunas: distribution, ecology, and conservation concerns. Oryx, 38, 311-320.

Henderson, R.W. \& Bourgeois, R.W. (1993) Notes on the diets of West Indian Liophis (Serpentes: Colubridae). Caribbean Journal of Science, 29, 253-254.

Honegger, R.E. (1981) List of amphibians and reptiles either known or thought to have become extinct since 1600 . Biological Conservation, 19, 141-158.

Jowers, M.J., Caut, S., Garcia-Mudarra, J.L., Alasaad, S. \& INEICH, I. (2013) Molecular phylogenetics of the possibly extinct Martinique ground snake. Herpetologica, 69, 227-236.

LAZELL, J.D. (1967) Wiederentdeckung von zwei angeblich ausgestorbenen Schlangenarten der westindischen Inseln. Salamandra, 3, 91-97.

Linnell, M.A., Engeman, R.M., Pitzler, M.E., Watten, M.O., Whitehead, G.F. \& Miller, R.C. (1998) An evaluation of two designs of stamped metal trap flaps for use in the operational trapping of brown tree snakes (Boiga irregularis). The Snake, 28, 14-18.

Moreau de Jonnès, A. (1818) Monographie de la Couleuvre couresse des Antilles Coluber cursor de Lacépède. Journal de Physique, 87, 193-200.

Myers, N., Mittermeier, R.A., Mittermeier, C.G., Da Fonseca, G.A.B. \& KENT, J. (2000) Biodiversity hotspots for conservation priorities. Nature, 403, 853-858.

Schwartz, A. \& Henderson, R.W. (1991) Amphibians and Reptiles of the West Indies. Descriptions, Distributions, and Natural History. University Press of Florida, Gainesville, USA.

Stuart, V. \& Eggleston, G.T. (1978) His Majesty's Sloop-of-War: Diamond Rock. Hale, London, UK.

Traill, L.W., Bradshaw, C.J.A. \& Brook, B.W. (2007) Minimum viable population size: a meta-analysis of 30 years of published estimates. Biological Conservation, 139, 159-166.

\section{Biographical sketches}

Stephane CaUt studies the ecology and conservation of threatened species. Much of his work focuses on ecosystem functioning and the key role played by vertebrate species and/or invasive species. Using a multidisciplinary approach (field, laboratory, modelling, and experimental), he seeks to understand biological and trophic interactions among species. He specializes in isotopes, using them to address species- and ecosystem-level conservation challenges across a wide range of taxa and habitats. MICHAEL JOWERS studies evolutionary biology, applying population genetics, phylogeography, and biogeography. He uses the phylogenetic species concept to assess the taxonomy of poorly described reptiles and amphibians. Most of his work has focused on reptiles and amphibians native to the islands of Trinidad and Tobago but he has also worked on other organisms, including mammals, social insects, scorpions, freshwater fish and parasites. 